Deterministic and Stochastic Models of AIDS Epidemics and HIV Infections with Intervention 
This page intentionally left blank 


\title{
Deterministic and Stochastic Models of
} AIDS Epidemics and HIV Infections with Intervention

\author{
WAI-YUAN TAN \\ University of Memphis, USA \\ HULIN WU \\ University of Rochester, USA
}


Published by

World Scientific Publishing Co. Pte. Ltd.

5 Toh Tuck Link, Singapore 596224

USA office: 27 Warren Street, Suite 401-402, Hackensack, NJ 07601

UK office: 57 Shelton Street, Covent Garden, London WC2H 9HE

\section{British Library Cataloguing-in-Publication Data}

A catalogue record for this book is available from the British Library.

\section{DETERMINISTIC AND STOCHASTIC MODELS OF AIDS EPIDEMICS AND HIV INFECTIONS WITH INTERVENTION}

Copyright () 2005 by World Scientific Publishing Co. Pte. Ltd.

All rights reserved. This book, or parts thereof, may not be reproduced in any form or by any means, electronic or mechanical, including photocopying, recording or any information storage and retrieval system now known or to be invented, without written permission from the Publisher.

For photocopying of material in this volume, please pay a copying fee through the Copyright Clearance Center, Inc., 222 Rosewood Drive, Danvers, MA 01923, USA. In this case permission to photocopy is not required from the publisher.

ISBN 981-256-139-0

Typeset by Stallion Press

Email: enquiries@stallionpress.com

Printed in Singapore. 


\section{CONTENTS}

Chapter 1

Mathematical Models for HIV Transmission Among

Injecting Drug Users

Vincenzo Capasso and Daniela Morale

Chapter 2

Estimation of HIV Infection and Seroconversion

Probabilities in IDU and Non-IDU Populations by State Space Models

Wai-Yuan Tan, Li-Jun Zhang and Lih-Yuan Deng

Chapter 3

A Bayesian Monte Carlo Integration Strategy

for Connecting Stochastic Models of HIV/AIDS

with Data

Charles J. Mode

Chapter 4

A Class of Methods for HIV Contact Tracing in Cuba: Implications for Intervention and Treatment

Ying-Hen Hsieh, Hector de Arazoza, Rachid Lounes and Jose Joanes

\section{Chapter 5}

Simultaneous Inferences of HIV Vaccine Effects on Viral Load, CD4 Cell Counts, and Antiretroviral Therapy Initiation in Phase 3 Trials Peter B. Gilbert and Yanqing Sun 
Chapter 6

A Review of Mathematical Models for HIV/AIDS Vaccination

Shu-Fang Hsu Schmitz

Chapter 7

Effects of AIDS Vaccine on Sub-Populations of $\mathrm{CD}^{(+)} \mathbf{T}$ Cells, CD8 ${ }^{(+)} \mathbf{T}$ Cells and B Cells Under HIV Infection

Wai-Yuan Tan, Ping Zhang and Xiaoping Xiong

Chapter 8

Dynamical Models for the Course of an HIV Infection

Christel Kamp

Chapter 9

How Fast Can HIV Escape from Immune Control?

W. David Wick and Steven G. Self

Chapter 10

CTL Action During HIV-1 Is Determined VIA

Interactions with Multiple Cell Types

Seema H. Bajaria and Denise E. Kirschner

Chapter 11

Identifiability of HIV/AIDS Models

Annah M. Jeffrey and Xiaohua Xia

Chapter 12

Influence of Drug Pharmacokinetics on HIV

Pathogenesis and Therapy

Narendra M. Dixit and Alan S. Perelson

Chapter 13

A Model of HIV-1 Treatment: The Latently Infected $\mathrm{CD}^{+}{ }^{+} \mathrm{T}$ Cells becomes Undetectable Karen O'Hara 
Chapter 14

A State Space Model for HIV Pathogenesis Under Anti-Viral Drugs and Applications

Wai-Yuan Tan, Ping Zhang and Xiaoping Xiong

Chapter 15

Bayesian Estimation of Individual Parameters in an HIV Dynamic Model Using Long-Term Viral Load Data

Yangxin Huang and Hulin Wu

Chapter 16

Within-Host Dynamics and Treatment of HIV-1

Infection: Unanswered Questions and Challenges for

Computational Biologists

John Mittler

Chapter 17

Treatment Interruptions and Resistance: A Review

Jane $M$ Heffernan and Lindi $M$ Wahl

Chapter 18

A Branching Process Model of Drug Resistant HIV

H. Zhou and K. S. Dorman

Chapter 19

A Bayesian Approach for Assessing Drug Resistance in HIV Infection Using Viral Load

Hua Liang, Waiyuan Tan and Xiaoping Xiong

Chapter 20

Estimating HIV Incidence from a Cross-Sectional

Survey with the Less Sensitive Assay

Robert H. Byers, Jr., Dale J. Hu and Robert S. Janssen

Chapter 21

Design of Population Studies of HIV Dynamics

Cong Han and Kathryn Chaloner 
Chapter 22

Statistical Estimation, Inference and Hypothesis Testing of Parameters in Ordinary Differential Equations Models of HIV Dynamics

Sarah Holte

\section{Chapter 23}

Convergence to an Endemic Stationary Distribution in a Class of Stochastic Models of HIV/AIDS in Homosexual Populations

Charles J. Mode

Index 